\title{
Genital Herpes and pregnancy
}

\section{Kaoutar Laamari*, Zakia Douhi, Sara Elloudi, Hanane Baybay, Fatima Zahra Mernissi}

Department Of Dermatology, University Hospital Hassan II Fez, Morocco

* Corresponding Author: Kaoutar Laamari, Department of Dermatology and Venerology, University Hospital Hassan II Fez, Morocco. Email: kaoutar.laamari1@gmail.com

Received date: December 19, 2019; Accepted date: January 02, 2020; published date: January 13, 2020

Citation: Kaoutar L, Zakia D, Sara E, Hanane B, Fatima ZM (2020) Genital Herpes and pregnancy. J Clinical Research and Reports, 2(1); DOI: $10.31579 /$ jcrr.2020/011

Copyright: (C) 2020 Kaoutar L. This is an open access article distributed under the Creative Commons Attribution License, which permits unrestricted use, distribution, and reproduction in any medium, provided the original work is properly cited.

Female patient aged 30 , at 7 months of pregnancy, admitted to gynecology for genital pain associated with pruritus that has been evolving for one week .

On clinical examination, she presents a vulvar edema, ulceration with polycyclic contours and some vesicles on the periphery. The diagnosis of herpes genital was confirmed. (fig 1). The patient took an antiviral treatment.

Genital herpes is a sexually transmitted disease caused by the herpes simplex virus (HSV). It is the most frequent cause of genital ulceration worldwide. (1)

Clinically, it is presented by vesicles grouped in bouquet with polycyclic contours genital and even anal patients may be asymptomatic or have pain or pruritus with a regional lymphadenopathy. Although the treatment of this entity is well codified, the risk remains to develop neonatal herpes especially in asymptomatic patients.

Use of condoms and antiviral medications is important in preventing transmission. (2)

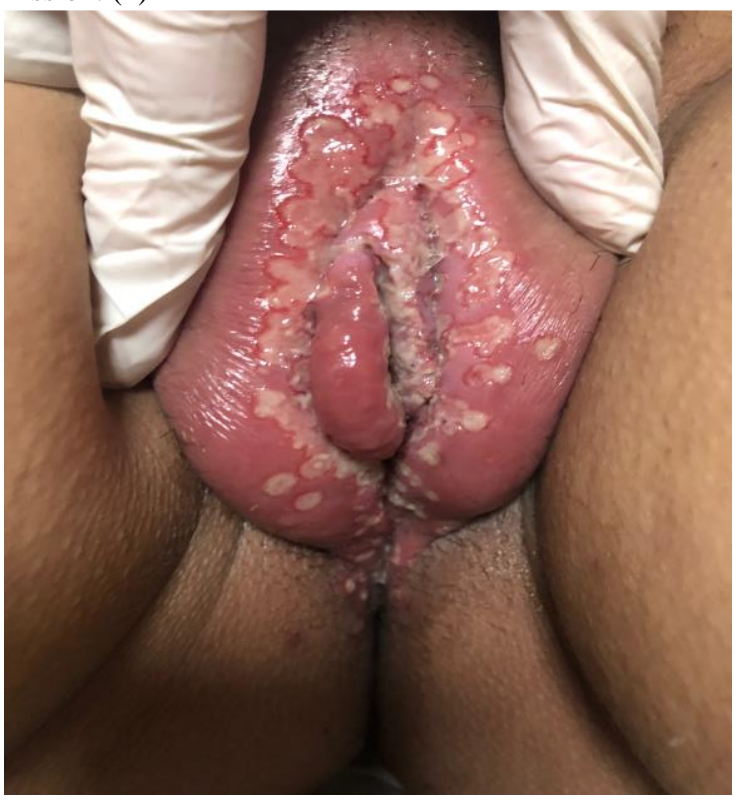

Ulceration with polycyclic contours and some vesicles on the periphery

\section{References}

1. Picone O. Herpe' s ge'nital et al ((2017)) grossesse : epidemiologie, manifestations de la maladie, pre'vention et de'pistage. Recommandations pour la pratique clinique du Colle'ge national des gyne' cologues obste'triciens franc ais (CNGOF). Gyne' cologie Obste 'trique Fertilite' \& Se'nologie.

2. S.M. Garland, M. Steben (2014) Best Practice \& Research Clinical Obstetrics and Gynaecology 28. 1098e 1110
Ready to submit your research? Choose Auctores and benefit from:

* fast, convenient online submission

* rigorous peer review by experienced research in your field

* rapid publication on acceptance

* authors retain copyrights

* unique DOI for all articles

* immediate, unrestricted online access

At Auctores, research is always in progress.

Learn more www.auctoresonline.org/journals/clinical-cardiologyand-cardiovascular-interventions 